\begin{tabular}{l|l|l|l|l}
\hline Volume 2 & Issue 3 & December (2021) & DOI: 10.47540/ijsei.v2i3.333 & Page: $227-234$ \\
\hline
\end{tabular}

\title{
Biostimulatory Influence of Biochar on Degradation of Petroleum Hydrocarbon Impacted Soil
}

\author{
Michael E. Nkereuwem ${ }^{1}$, Afeez O. Amoo ${ }^{2}$, Adeniyi O. Adeleye ${ }^{3}$, Hafsat S. Abubakar ${ }^{4}$, Victor \\ O. Onokebhagbe ${ }^{5}$, Fatimah Kamaldeen ${ }^{6}$ \\ ${ }^{1,5,6}$ Department of Soil Science, Federal University Dutse, Nigeria \\ ${ }^{2,3,4}$ Department of Environmental Sciences, Federal University Dutse, Nigeria
}

Corresponding Author: Michael E. Nkereuwem; Email: michael.n@fud.edu.ng

\begin{tabular}{|c|c|}
\hline A R T I C L E I N F O & A B S T R A C T \\
\hline $\begin{array}{l}\text { Keywords: Bacteria Population; } \\
\text { Biochar; Bone Char; Total Petroleum } \\
\text { Hydrocarbon; Wood Char. }\end{array}$ & $\begin{array}{l}\text { Soil pollution caused by petroleum hydrocarbon and its derivatives has become a } \\
\text { grave global issue. Physico-chemical techniques are often expensive. However, } \\
\text { bioremediation of petroleum hydrocarbon polluted soil is cost-effective. Therefore, }\end{array}$ \\
\hline : 31 August 2021 & degradation of petroleum hydrocarbon impacted soil in NNPC Depot, kano state. \\
\hline Revised : 23 December 2021 & Soil samples were randomly collected from the polluted site to obtain a composite \\
\hline$: 25$ December 2021 & $\begin{array}{l}\text { sample. About } 400 \mathrm{~g} \text { of the polluted soil was filled into pots and arranged in a } 2 \times 2 \\
\text { factorial experiment in a completely randomized design with three replications. } \\
\text { Bone and wood char was at } 2 \text { levels }(0 \text { and } 50 \mathrm{~g} / \mathrm{pot}) \text { each. Data were collected on } \\
\text { the physicochemical properties (pH, TN, and Av. P) of the soil, Total Petroleum } \\
\text { Hydrocarbon (TPH), and bacterial population. Data were analyzed using ANOVA }\end{array}$ \\
\hline & $\begin{array}{l}\text { at } \alpha_{0.05} \text {. Results obtained from the study show that biochar application significantly } \\
(\mathrm{p}<0.05) \text { enhanced TPH degradation and bacterial population in the polluted soil. } \\
\text { However, Bone char significantly }(\mathrm{p}<0.05) \text { enhanced TPH degradation and bacterial } \\
\text { population the most compared to wood char. Combined bone and wood char } \\
\text { application resulted in significantly ( } \mathrm{p}<0.05) \text { lower residual TPH content in the } \\
\text { polluted soil compared to using bone or wood char alone. Thus, bone and wood } \\
\text { char should be used in the bioremediation of petroleum hydrocarbon impacted soils. }\end{array}$ \\
\hline
\end{tabular}

\section{INTRODUCTION}

Soil pollution due to petroleum and its derivatives has turned into a serious global issue. Petroleum hydrocarbons are found in nature and are used as the primary source of energy for both households and businesses. According to Erdogan and Karaka (2011); Bijay et al. (2012); Ofoegbu et al. (2014), vandalization of oil infrastructures, corrosion of old oil facilities and uncontrolled spilling in petroleum processing plants and storage tanks are causes of crude oil spillage. Crude oil, according to Erdogan and Karaka (2011), contains several hazardous compounds in slightly high fixations thus, it is physically, synthetically, and biologically damaging to the soil. It is spilled on the ground surface, where it slowly seeps into the soil resulting in soil fertility depletion. Environmental deterioration, groundwater contamination, biodiversity loss, and the threat to natural environmental sustainability are some of the effects of crude oil pollution (Bijay et al., 2012; Ofoegbu et al., 2014). Naturally, crude oil persists in soil far more than other carbon sources namely proteins and carbs, which take weeks to break down, and it lasts much longer under extreme conditions such as drought (Ali et al., 2020).

The buildup of contaminants in animals and plant tissue due to soil pollution with petroleum hydrocarbons may result in mortality and mutations due to substantial harm of internal structure (Alvarez and Vogel, 2011). Physicochemical methods such as soil washing, solidification, vapor extraction, thermal desorption, etc. used in the treatment of petroleum hydrocarbon polluted soils have been proposed (Frick et al., 1999; Dadrasnia et al., 2015). However, these methods have some 
drawbacks as they are expensive and have limited local applications (Dadrasnia et al., 2015). Additionally, they do not usually result in the complete destruction of the contaminants. Bioremediation, on the other hand, which is the use of living creatures, most notably microbes, to break down pollutants in the surroundings into less hazardous forms, has shown promising results and it is economically and ecologically friendly (Nkereuwem et al., 2020). It degrades or detoxifies pollutants that are harmful to human health and/or the surrounding using naturally occurring microbes or plants through biostimulation (addition of nutrients/amendments) of the indigenous populations or bioaugmentation with oxidizing microorganisms (Adeleye et al., 2019).

Many elements, such as nutrients, $\mathrm{pH}$, temperature, moisture, oxygen, soil characteristics, and the presence of contaminants, might inhibit petroleum hydrocarbon decay in soil (Adeleye et al., 2019). Biochar, according to Xiao et al. (2014), is carbon-rich charcoal produced by pyrolysis (thermal decomposition) of organic biomass or agricultural wastes and used as a soil amendment. It is made up of varying quantities of carbon (C), hydrogen $(\mathrm{H})$, oxygen $(\mathrm{O})$, nitrogen $(\mathrm{N})$, Sulphur (S), and ash. It's mostly used to increase soil nutrient content and sequester carbon from the atmosphere (Lehmann, 2009). When put to the soil, biochar has been shown to provide a number of environmental benefits, including increased soil fertility, improved plant growth, and the breakdown of pollutants (Novak et al., 2010).

Given the negative impacts of crude oil pollution on soil organisms and plants, as well as the implications for food security and environmental safety, the quest for a better alternative method of treating petroleum hydrocarbon impacted soil that is cheap and readily available becomes imperative. The objectives of the present study were to 1) assess the efficacy of Bone-char and Wood-char in degrading Total Petroleum Hydrocarbon (TPH) content in petroleum hydrocarbon polluted soil and 2) determine the combinatorial effect of Bone-char and Wood-char in the degradation of TPH in petroleum hydrocarbon impacted soil.

\section{MATERIALS AND MeThodS}

\section{Study area and location}

This research was conducted using petroleum hydrocarbon polluted soil samples from Kano Depot of Nigeria National Petroleum Company (NNPC)/Pipelines and Products Marketing Company (PPMC), Kano State, Nigeria. Kano State is made up of 44 local government areas with Kano Municipal as the capital city. NNPC/PPMC Depot is in Tarauni local government area and it is located on latitude $8^{\circ} 57^{\prime} 55.76 "$ north and longitude $11^{\circ} 96^{\prime} 91.38^{\prime \prime}$ ' east.

\section{Soil sample collection and preparation}

Soil samples collection was done as described by Nkereuwem et al. (2010). Topsoil $(0-20 \mathrm{~cm})$ samples were randomly collected, air-dried, sifted using a two-millimeter sifter. The sifted samples were then packed inside polyethylene bags.

\section{Biochar production}

The bone and wood chars were produced by pyrolysis of cattle bone and wood at the Department of Soil Science Laboratory, Federal University Dutse, Dutse, Jigawa State, Nigeria, using the procedure described by Onokebhagbe et al. (2018). The products of the pyrolysis were then sieved using a $2 \mathrm{~mm}$ sieve. This was done to ensure uniformity in particle size. The biochar was chemically analyzed using the procedure outlined by Beesley et al. (2010).

\section{Design of the experiment}

It was a two-factor factorial experiment with four treatment combinations: Bone-char at twolevel $(0$ and $50 \mathrm{~g} /$ pot $)$ and Wood-char at two-level ( 0 and $50 \mathrm{~g} / \mathrm{pot})$. This was laid out in a completely randomized design and replicated 3 times.

Factors:

1. Bone char at 2 levels $(\mathrm{B}=$ bone char)

a. Without bone char $\left(\mathrm{B}_{1}-0 \mathrm{~g} / \mathrm{pot}\right)$

b. With bone char $\left(\mathrm{B}_{2}-50 \mathrm{~g} /\right.$ pot $)$

2. Wood char at 2 levels $(\mathrm{W}=$ wood char $)$

a. Without wood char $\left(\mathrm{W}_{1}-0 \mathrm{~g} / \mathrm{pot}\right)$

b. With wood char $\left(\mathrm{W}_{2^{-}}-50 \mathrm{~g} /\right.$ pot $)$

The treatments are listed thus: $\mathrm{B}_{1} \mathrm{~W}_{1}, \mathrm{~B}_{1} \mathrm{~W}_{2}, \mathrm{~B}_{2} \mathrm{~W}_{1}$, $\mathrm{B}_{2} \mathrm{~W}_{2}$

\section{Biodegradation Assay/pot trial}

About $400 \mathrm{~g}$ of the polluted soil was weighed into twelve (12) experimental pots. Thereafter, biochar (bone and wood char) was applied to the potting soil at 0 and $50 \mathrm{~g} /$ pot, respectively. The biochar was mixed thoroughly with the soil for even 
distribution. Moisture was maintained through the application of sterile distilled water $(25 \mathrm{~mL})$ twice a week (Abioye et al., 2012). The experiment lasted for 8 weeks.

\section{Data collection}

The TPH accumulation in the soil as well as selected physicochemical properties of the soil were determined at the end of the experiment. The bacterial colony count and identification were also carried out.

Analysis of the soil sample's physical and chemical features

Particle size determination was calculated using the hydrometer procedure as outlined by Bouyoucous (1951), and the soil $\mathrm{pH}$ was obtained using the procedure outlined by Udoh and Ogunwale (1986). Walkley-Black's modified technique as described by Nelson and Sommers (1996), was used to calculate the organic carbon. The micro Kjeldahl digestion and distillation technique, as reported by Udo and Ogunwale (1986), and the Bray P 1 procedure as outlined by Bray and Kurtz (1945), were used to determine the total nitrogen and accessible phosphorous concentrations of the soil. Potassium, sodium, calcium and magnesium were calculated using the procedure outlined by Jackson (1958); calcium and magnesium were measured with an AAS, whereas potassium and sodium were measured with flame photometry. The effective cation exchange capacity was evaluated using the technique outlined by Juo et al. (1976), whereas the procedure outlined by Mclean (1982), was used to measure the exchangeable acidity.

Microbial enumeration of bacteria and biochemical test

The number of viable bacteria was estimated using the plate count technique (Ochei and Kolhatkar, 2008) while a biochemical test was done as described by Barrow and Feltham (1993).

\section{The total petroleum hydrocarbon (TPH)}

Total Petroleum Hydrocarbon (TPH) was determined using the US EPA $1850 \mathrm{C}$ method described by USEPA (2003).

\section{Data analysis}

Proc. GLM of GenStat version 17 was used to perform analysis of variance (ANOVA) on all data obtained, and significant means were separated using appropriate post-hoc methods.

\section{RESULTS AND DisCUSSION}

Table 1. Physical and Chemical Features of The Polluted Soil

\begin{tabular}{|c|c|c|}
\hline \multirow{2}{*}{ Parameters } & \multicolumn{2}{|c|}{ Value } \\
\cline { 2 - 3 } & Before Amendment & After Amendment \\
\hline $\mathrm{pH}\left(\mathrm{H}_{2} \mathrm{O}\right)$ & $\mathbf{7 . 3}$ & $\mathbf{8 . 0}$ \\
\hline Total Nitrogen $(\%)$ & 1.5 & 2.55 \\
\hline Av. Phosphorus $(\mathrm{m} / \mathrm{kg})$ & 62 & 46 \\
\hline Electrical conductivity $(\mu \mathrm{S} / \mathrm{cm})$ & 1.01 & 1.32 \\
\hline Exchangeable bases $(\mathbf{c m o l} / \mathbf{k g})$ & & 3.9 \\
\hline Calcium & 4.1 & 1.4 \\
\hline Magnesium & 1.9 & 0.08 \\
\hline Sodium & 0.06 & 0.35 \\
\hline Potassium & 0.34 & 69 \\
\hline Particle size (\%) & & 16 \\
\hline Sand & 72 & 15 \\
\hline Silt & 10 & Sandy loam \\
\hline Clay & 18 & \\
\hline Textural class & Sandy loam & \\
\hline
\end{tabular}

The physical and chemical features of the polluted soil are listed in Table 1 . The $\mathrm{pH}$, total nitrogen, and Av. Phosphorus before and after biochar amendment are $7.3,1.5 \%$ and $62 \mathrm{mg} / \mathrm{kg}$ and $8.0,2.55 \%$ and $46 \mathrm{mg} / \mathrm{kg}$, respectively. The textural class of the soil is sandy loam. 
Table 2. Selected Chemical Parameters of Biochars

\begin{tabular}{|c|c|c|}
\hline Property & Bone char & Wood char \\
\hline $\mathrm{pH}$ & 7.5 & 8.9 \\
\hline Total Nitrogen $(\mathrm{g} / \mathrm{kg})$ & 20.3 & 5.45 \\
\hline Total Phosphorus $(\mathrm{g} / \mathrm{kg})$ & 54.1 & 1.70 \\
\hline Potassium $(\mathrm{cmol} / \mathrm{kg})$ & 3.4 & 12.6 \\
\hline
\end{tabular}

Selected chemical properties of the biochar (bone and wood chars) are presented in Table 2.

Table 3. Effects of Bone and Wood char on Total Petroleum Hydrocarbon (TPH) contents of polluted soil at 8 weeks

\begin{tabular}{|l|l|}
\hline Treatments & Total Petroleum Hydrocarbon $\mathbf{( m g} / \mathbf{k g})$ \\
\hline Bone char & \\
\hline B1 & $324.4 \mathrm{a}$ \\
\hline B2 & $149.3 \mathrm{~b}$ \\
\hline LSD & 8.02 \\
\hline Wood char & \\
\hline W1 & $283.2 \mathrm{a}$ \\
\hline W2 & $190.4 \mathrm{~b}$ \\
\hline LSD & 8.04 \\
\hline
\end{tabular}

$\mathrm{LSD}=$ Least significant difference, $\mathrm{B} 1=$ Bone char at $0 \mathrm{~g} /$ pot, $\mathrm{B} 2=$ Bone char at $50 \mathrm{~g} / \mathrm{pot}$

$\mathrm{W} 1=$ wood char at $0 \mathrm{~g} /$ pot, $\mathrm{W} 2=$ wood char at $50 \mathrm{~g} /$ pot

Significantly lower $(149.3 \mathrm{mg} / \mathrm{kg}) \quad \mathrm{TPH}$ volume of the polluted soil was obtained with bone char application (Table 3) compared to treatment resulted in significantly lower $(190.4 \mathrm{mg} / \mathrm{kg}) \mathrm{TPH}$ quantity of the polluted soil compared to treatment with no bone char. Similarly, wood char application with no wood char (Table 3).

Table 4. Interactions of Bone char with Wood char on Total Petroleum Hydrocarbon (TPH) contents of polluted soil

\begin{tabular}{|l|l|l|}
\hline Bone char & Wood char & Total petroleum hydrocarbon $\mathbf{( m g / k g )}$ \\
\hline B1 & W1 & $400.9 \mathrm{a}$ \\
\hline B1 & W2 & $247.9 \mathrm{~b}$ \\
\hline B2 & W1 & $165.6 \mathrm{c}$ \\
\hline B2 & W2 & $132.9 \mathrm{~d}$ \\
\hline & LSD & 11.35 \\
\hline
\end{tabular}

$\mathrm{B} 1=\mathrm{Bone}$ char at $0 \mathrm{~g} /$ pot, $\mathrm{B} 2=$ Bone char at $50 \mathrm{~g} /$ pot

$\mathrm{W} 1=$ wood char at $0 \mathrm{~g} /$ pot, $\mathrm{W} 2=$ wood char at $50 \mathrm{~g} /$ pot

Combined application of bone char at $50 \mathrm{~g} / \mathrm{pot}$ with wood char at $50 \mathrm{~g} /$ pot resulted in significantly $(\mathrm{p}<0.05) \quad$ lower $\quad(132.9 \mathrm{mg} / \mathrm{kg}) \quad$ residual total petroleum hydrocarbon quantity of the soil in comparison to the other treatments (Table 4). Significantly $(\mathrm{p}<0.05)$ higher $\quad(400.9 \quad \mathrm{mg} / \mathrm{kg})$ residual TPH content of the soil was gotten from the combination of $0 \mathrm{~g} / \mathrm{bag}$ bone char with $0 \mathrm{~g} / \mathrm{pot}$ wood char compared to those of $0 \mathrm{~g} /$ pot bone char with $50 \mathrm{~g} /$ pot wood char and $50 \mathrm{~g} /$ pot bone char with $0 \mathrm{~g} /$ pot wood char. Furthermore, combined application of $50 \mathrm{~g} /$ pot bone char with $0 \mathrm{~g} /$ pot wood char also resulted in significantly $(\mathrm{p}<0.05)$ lower $(165.6 \mathrm{mg} / \mathrm{kg})$ residual total petroleum hydrocarbon

quantity of the soil in comparison to the combined application of $0 \mathrm{~g} /$ pot bone char with $50 \mathrm{~g} /$ pot wood char (Table 4). 
Table 5. Effects of Bone and Wood char on Bacterial Colony Count (CFU/g soil) of petroleum hydrocarbon polluted soil

\begin{tabular}{|l|l|}
\hline \multicolumn{1}{|c|}{ Treatments } & \multicolumn{1}{|c|}{$\begin{array}{c}\text { Bacterial colony count } \\
\text { (CFU/g soil) }\end{array}$} \\
\hline Bone char & \\
\hline B1 & 1.77 \\
\hline B2 & 3.43 \\
\hline LSD & 1.28 \\
\hline Wood char & \\
\hline W1 & 2.10 \\
\hline W2 & 3.10 \\
\hline LSD & NS \\
\hline
\end{tabular}

Bone char application at $50 \mathrm{~g} /$ pot resulted in significantly higher $(3.43 \mathrm{CFU} / \mathrm{g}$ ) bacterial colony count compared to $0 \mathrm{~g} /$ pot bone char (Table 5) while 50 and $0 \mathrm{~g} /$ pot wood char applications did not considerably differ although the use of $50 \mathrm{~g} / \mathrm{pot}$ wood char yielded greater bacterial count (Table 5). The outcome of this research shows proliferation in culturable bacterial count. However, treatments amended with biochar had significantly higher bacterial counts.

Table 6. Bacteria identification according to Biochemical characteristics

\begin{tabular}{|c|c|c|c|c|c|c|}
\hline Organisms & Coagulase & Catalase & Oxidase & $\begin{array}{c}\text { Citrate } \\
\text { utilization }\end{array}$ & $\begin{array}{c}\text { Nitrite } \\
\text { reduction }\end{array}$ & Urease \\
\hline $\begin{array}{c}\text { Streptoceous } \\
\text { pyogeus }\end{array}$ & - & - & - & - & - & - \\
\hline $\begin{array}{c}\text { Staphylococcus } \\
\text { epidermis }\end{array}$ & - & + & - & - & + & + \\
\hline $\begin{array}{c}\text { Pseudomonas } \\
\text { aeruginosa }\end{array}$ & - & + & + & + & + & - \\
\hline
\end{tabular}

Note: $+=$ positive; $-=$ negative

From the biochemical characteristics test (Table 6), three organisms were identified namely Streptoceous pyogeus, Staphylococcus epidermis, and Pseudomonas aeruginosa (Table 6).

The findings of this study are consistent with those of Ikiogha et al. (2019), for tropical rainforest soils. This study's findings also support recent research by Nkereuwem et al. (2020 a and b), who found a rise in Total nitrogen in crude oilcontaminated soil treated with organic stimulants.

The enhanced TPH degradation observed in this research corroborates the results of Agarry et al. (2013), where a higher degradation rate constant due to biochar application in crude oil polluted soil was observed. The increased TPH degradation seen in this study could be due to the biochar used (bone and wood chars) acting as a bio-stimulant, enhancing nutrient availability, particularly phosphorus and micronutrients (Chan and $\mathrm{Xu}$, 2009; Park et al., 2011; Ikiogha et al., 2019). These elements form the fundamental building elements of life, allowing microorganisms to flourish and generate the enzymes required to break down petroleum hydrocarbon pollutants. Despite the presence of microorganisms in polluted soil, their numbers may not be adequate to begin cleanup.
Studies have shown that hydrocarbonoclastic bacteria require nitrogen, phosphorus, and carbon as building components, thus they must be stimulated in their growth and activities. Nitrogen is required for the synthesis of cellular proteins and cell walls, whereas $\mathrm{P}$ is required in the formation of nucleic acids, cell membranes, and adenosine triphosphate. Thus, bioremediation of polluted soil requires a sufficient provision of the above-mentioned nutrients, which are in turn utilized by hydrocarbonoclastic micro-organisms for their vigorous development and metabolousoperation (Adeleye et al., 2018; Nkereuwem et al., 2020). Nutrient deficiency in petroleum hydrocarbon polluted soils inhibit bio-remediation; nevertheless, soil hydrocarbonoclastic microbes usually gain from nutrients addition leading to improved bioremediation of hydrocarbon impacted habitat (Beolchini et al., 2010; Kauppi et al., 2011).

The result of this study shows the combinatorial efficacy of bone and wood char in the degradation of TPH in petroleum hydrocarbon polluted soil. The optimum TPH degradation observed in the combined application of $50 \mathrm{~g} / \mathrm{pot}$ bone char and $50 \mathrm{~g} /$ pot wood char could be linked to the synergistic effect of bone and wood char. 
Similar outcomes were also recorded by Ugwoha et al. (2020), where they noted improved bioremediation of crude-petroleum impacted soil through the combined application of pig droppings and bone char mixture. The results of this study also corroborate the findings of Ikiogha et al. (2019), where they reported a substantial decrease in TPH content of crude oil contaminated soil due to the combined application of NPK fertilizer and bone char. The reason for the observed reduction in TPH could be because biochar improves soil qualities such as water holding capacity, nutritional status, etc., and total microbial count as reported by Wang et al. (2017). Furthermore, due to the presence of pore spaces and a large surface area, biochar can provide superior support for microbial development (Wang et al., 2017) thereby increasing petroleum hydrocarbon-degrading microbial communities.

This result confirms the outcome of Nwogu et al. (2015), where they noted an increase in the population of culturable hydrocarbon utilizing bacteria due to soil amendment. The increase in bacterial counts, according to Atlas and Bartha (1992), could be attributed to extra microbic communities, which employed intermediate commodities due to hydrocarbon degradation. The microbial counts recorded in this research conform with previous results by Ijah et al. (2003) and Nwogu et al. (2015). The bacterial genera isolated were Streptococcus pyogens, Staphylococcus epidermis, and Pseudomonas aeruginosa. These organisms have previously been identified by Bento et al. (2005); Onuoha (2013) and Nkereuwem et al. (2020), as microbes that utilize hydrocarbon during bio-remediation of crude oil impacted soils.

\section{CONCLUSION}

Biochar treatment considerably increases the bacteria population in the polluted soil, resulting in enhanced Total Petroleum Hydrocarbon (TPH) reduction, according to the findings of this study. Furthermore, the physicochemical properties of the soil were also influenced positively due to biochar application. All of the soil samples tested showed a reduction in Total Petroleum Hydrocarbons (TPH). However, when comparing treatments with and without biochar, the quantity removed was much higher with biochar application. Due to its considerable performance in TPH degradation as observed in this study, the application of biochar in bioremediation of petroleum hydrocarbon impacted soil is thus advocated.

\section{REFERENCES}

Abioye, O. P.; Agamuthu, P. \& Abdul-Aziz, R.A. (2012). Biodegradation of Used Motor Oil using Organic Waste Amendment. Hindawi Publishing Corporation. Biotechnology Research

Adeleye, A.O. \& Yerima, M.B. (2019). Isolation and Identification of Spent Engine Oil Utilizing Bacteria from Mechanic Village Dutse, Jigawa State. Paper presented at the $42^{\text {nd }}$ Conference of the Nigerian Society for Microbiology. Crawford University, Igbesa, Ogun State.

Adeleye, A. O.; Yerima, M. B., Nkereuwem, M. E., Onokebhagbe, V. O., Shiaka, P. G., Amoo, F. K. \& Adam, I. K. (2019). Effect of organic amendments on the decontamination potential of heavy metals by Staphylococcus aureus and Bacillus cereus in soil contaminated with spent engine oil. Novel Research in Microbiology Journal. 3(5): 471-484.

Adeleye, A. O., Nkereuwem, M. E., Omokhudu, G. I., Amoo, A. O., Shiaka, G. P. \& Yerima, M. B. (2018). Effect of Microorganism in the Bioremediation of Spent Engine Oil and Petroleum Related Environmental Pollution. J. Appl. Sci. Environ. Manage. 22(2): 157167.

Agarry, S. E; Aremu, M. O; \& Aworanti, O. A. (2013a). Kinetic modelling and half-life study on bioremediation of soil cocontaminated with lubricating motor oil and lead using different bioremediation strategies. Soil and Sediment Contam. - An Int. J. 22 (7): 800-816.

Agarry, S. E; Aremu, M. O; \& Aworanti, O. A. (2013b). Kinetic modelling and half-life study on enhanced soil bioremediation of bonny light crude oil amended with crop and animal-derived organic wastes. $J$. Pet Environ. Biotechnol. 4: 137.

Ali, N., Dashti, N., Khanafer, M., Al-Awadhi, H. \& Radwan, S. (2020). Bioremediation of soils saturated with spilled crude oil, Sci Rep. 10 (1):1116. 
Alvarez, P. J. J. \& Vogel, T. M. (2011). Substrate interactions of benzene, toluene, and paraxylene during microbial degradation by pure cultures and mixed culture aquifer slurries. Applied and Environmental Microbiology. 57 (10): 2981-2985.

Atlas, R. M. \& Bartha, R. (1992). Microbial Ecology: Fundamentals and Applications, Benjamin/Cumming Publishing Company, Menlo Park, Calif, USA.

Barrow, G. I. \& Feltham, R. K. A. (1993). Cowan and Steel's Manual for the Identification of Medical Bacteria. Cambridge University Press 3rd Edn Pp. 52-101.

Beesley, L., Moreno-Jiménez, E. \& Gomez-Eyles, J. L. (2010). Effects of biochar and green waste compost amendments on mobility, bioavailability and toxicity of inorganic and organic contaminants in a multi-element polluted soil. Environmental Pollution, 158: 2282-2287.

Bento, F. M., Camargo, F. A. O., Okeke, B. C. \& Frankenberger Jr., B. T. (2005). Comparative bioremediation of soils contaminated with diesel oil by natural attenuation, biostimulation and bioaugmentation. Bioresource Technology. 96 (9): 1049-1055.

Beolchini, F., Rocchetti, L., Regoli, F. \& Dell'Anno, A. (2010). Bioremediation of marine sediments contaminated by hydrocarbons: experimental analysis and kinetic modelling," Journal of Hazardous Materials. 182 (1-3): 403-407.

Bijay, T., Ajay, K. K. C. \& Anish, G. (2012). A review on bioremediation of petroleum hydrocarbon contaminants in soil. Kathmandu University Journal of Science, Engineering and Technology. 8 (I):164-170.

Bouyoucos, C. H. (1951). A recalibration of hydrometer method for making mechanical analysis of soils. Agronomy Journal. 43 (9): 434-438.

Bray, R. H. \& Kurtz, L.T. (1945). Determination of Total Organic and Available Forms of Phosphorus in Soils. Soil Science. (59): 3945.

Chan, K.Y. \& Xu, Z. (2009). Biochar: nutrient properties and their enhancement. In: Lehmann J., Joseph S. (Eds.), Biochar for
Environmental Management: Science and Technology. Earthscan, London.

Dadrasnia, A.; Salmah, I.; Emenike, C.U. \& Shahsavari, N. (2015). Remediation of oil contaminated media using organic material supplementation. Petroleum Science and Technology. (33): 1030-1037.

Erdogan, E. E. \& Karaca, A. (2011). Bioremediation of crude oil polluted soils. Asian Journal of Biotechnology. 3 (3): 206213.

Frick, C. M., Farrell, R. E. \& Germida J. J. (1999). Assessment of phytoremediation as an in-situ technique for cleaning oil-contaminated sites. Report submitted to Petroleum Technology Alliance of Canada.

Ijah, U. J. J. \& Antai, S. P. (2003). Removal of Nigerian light crude oil in soil over a 12 month period. International Biodeterioration and Biodegradation. 51 (2): 93-99.

Ikiogha, D., Otaraku, I., Momoh, Y. \& Welcome, M. (2019). Comparative effects of bone char and NPK agricultural fertilizers on hydrocarbon utilizing bacteria and fungi in crude oil polluted soil. Am. Scientific Res. J. Eng., Technol. Sci. (55): 35-49.

Kauppi, S., Sinkkonen, A. \& Romantschuk, M. (2011). Enhancing bioremediation of dieselfuel-contaminated soil in a boreal climate: comparison of biostimulation and bioaugmentation. International Biodeterioration and Biodegradation. 65 (2): 359-368.

Lehmann, J. (2009). Biological carbon sequestration must and can be a win win approaches. Climatic Change. (97): 459-463.

McLean, E. (1982). Soil pH and lime requirement. Methods of soil analysis. Part 2. Chemical and microbiological properties. 199 - 224.

Nelson, D.W. \& Sommers, L.E. (1996). Total carbon, organic carbon and organic matter. In: Methods of Soil Analysis, Part 2, 2nd ed., A.L. Page et al., Ed. Agronomy. 9:961-1010. American Society of Agronomy, Inc. Madison, WI.

Nkereuwem, M. E., Fagbola, O., Okon, I. E., Adeleye, A. O. \& Nzamouhe, M. (2020a). Bioremediation potential of mycorrhiza fungi in crude oil contaminated soil planted with 
Costus lucanusianus. Amazonian Journal of Plant Research. 4(1): 441-455.

Nkereuwem, M. E., Fagbola, O., Okon, I. E., Edem, I. D., Adeleye, A. O. \& Onokebhagbe, V. O. (2020b). Influence of a mycorrhizal fungus and mineral fertilizer on the performance of Costus lucanusianus under crude oil contaminated soil. Novel Research in Microbiology Journal. 4(3): 808-824.

Nkereuwem, M. E., Edem, I. D. \& Fagbola, O. (2010). Bioremediation of Oil-polluted soils with Organomineral Fertiliser (OMF) and Mexican Sunflower (Tithonia diversifolia). Nigerian Journal of Agriculture, Food and Environment. 6 (1 and 2): 13-20.

Novak, I., Kirkin, V., McEwan, D.G., Zhang, J., Wild, P., Rozenknop, A., Rogov, V., Löhr, F., Popovic, D. \& Occhipinti, A. (2010). Nix is a selective autophagy receptor for mitochondrial clearance. EMBO Rep.11: 4551.

Nwogu, T. P., Azubuike, C. C. \& Ogugbue C. J. (2015). Enhanced Bioremediation of soil artificially contaminated with petroleum Hydrocarbons after amendment with Capra aegagrus hirus (Goat) manure. Biotechnology Research International. ID 657349.

Ochei, J. O \& Kolhatkar, A. A. (2008). Medical Laboratory Science: Theory and Practice. Tata McGraw Publishing Company Limited.

Ofoegbu, R. U., Momoh, Y. O. L. \& Nwaogazie, I. L. (2014). Bioremediation of Crude Oil Contaminated Soil Using Organic and Inorganic Fertilizers. Journal of Petroleum \& Environmental Biotechnology. 6:1-6.

Onokebhagbe, O. V., Abdu, N. \& Santuraki, H. A. (2018). Residual effects of biochar on yield of grain amaranths (Amaranthus cruentus L.) grown on Alfisols of Nigerian Northern Guinea and Sudan savanna agro-ecologies. Dutse Journal of Agriculture and Food Security, 5 (1): 97-108.

Onuoha, S. C. (2013). Stimulated biodegradation of spent lubricating motor oil in soil amended with animal droppings. Journal of Natural Sciences Research. 3 (12): 106-116.

Park, J. H., Choppala, G. K., Bolan, N. S., Chung, J. W. \& Chuasavathi, T. (2011). Biochar reduces the bioavailability and phytotoxicity of heavy metals. Plant Soil. (348): 439-451.
Udo, E.J. \& Ogunwale, J.A. (1986). Laboratory Manual for Analysis of Soil, Plant and Water Samples. University Press Ibadan.

Ugwoha, E. \& Iwuchukwu, O. L. (2020). Modeling the Bioremediation of Petrol Contaminated Soil by Clogged-Drainage Bacteria. Uniport Journal of Engineering and Scientific Research. 5 (SI):7 1-81.

U.S. EPA. (2003). Method 8015C (SW-846): Nonhalogenated Organics Using GC/FID, Revision 4. Washington, DC.

Wang, Tong-tong, M. A. Jiang-bo, QU Dong. (2017). Characteristics and mechanism of copper adsorption from aqueous solutions on biochar produced from sawdust and apple branch. Journal of Environmental Science. 38 (5): 2161-2171.

Xiao, X., Chen, B., Lizhong, Z. (2014). Transformation, morphology and dissolution of silicon and carbon in rice straw derived biochars under different pyrolytic temperatures. Environmental Science \& Technology. (48): 3411-3419. 